SHORT REPORT

\title{
Bell's palsy with ipsilateral numbness
}

\section{J Vanopdenbosch, K Verhoeven, J W Casselman}

J Neurol Neurosurg Psychiatry 2005;76:1017-1018. doi: 10.1136/jnnp.2004.043059

Bell's palsy is an idiopathic facial palsy of the peripheral type. A herpes virus is the most likely mechanism. We report a patient with the often encountered combination of a facial palsy with ipsilateral sensory changes. Magnetic resonance imaging showed had contrast enhancement in the greater petrosal nerve. Viral spread through anatomical connections could be an explanation for the association of facial palsy with numbness.

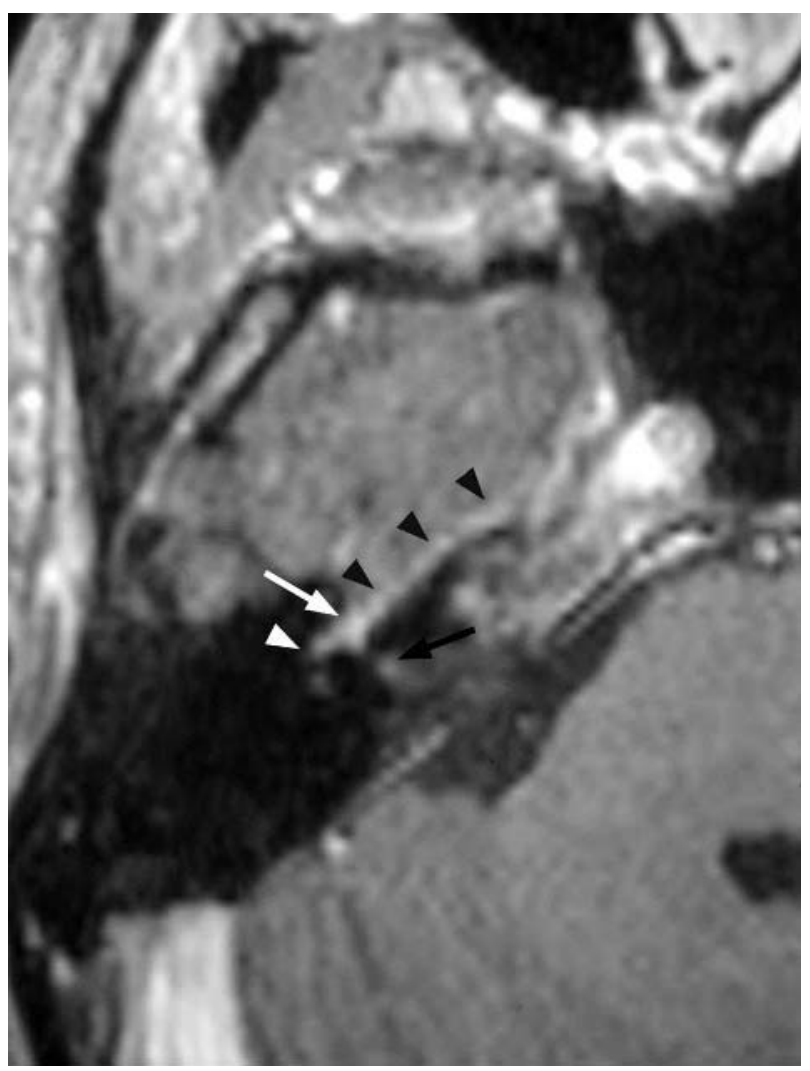

Figure 1 Axial $1 \mathrm{~mm}$ thick gadolinium enhanced $\mathrm{T} 1$ weighted image through the geniculate ganglion (white arrow). Right lower corner shows the pons, fourth ventricle, middle cerebellar peduncle, and part of the cerebellum; left upper corner shows temporal bone and masticatory muscles. Enhancement of the facial nerve can be seen at the fundus of the internal auditory canal (black arrow), at the level of the geniculate ganglion (white arrow) and in the tympanic segment of the facial nerve (white arrowhead). Moreover, enhancement can be seen along the course of the superficial greater petrosal nerve (black arrowheads) following the border of the petrous apex and the superolateral border of the internal carotid artery.
B ell's palsy is defined as an idiopathic facial palsy of the peripheral type: involvement of upper and lower face with or without loss of taste ipsilaterally in the tongue. A viral mechanism with herpes simplex is postulated and widely accepted. ${ }^{1}$ Usually the course is benign, with full recovery in 2-3 weeks time. The lifetime risk is estimated at $2 \% .^{2}$ Not uncommonly a hypoaesthesia to pinprick is found in the paretic area on clinical neurological examination. ${ }^{3}$ Baffling some neurologists and sparking elaborate brain stem theories ${ }^{4}$ or being termed Bell's acute benign cranial polyneuritis, ${ }^{3}$ more often examining neurologists tend to scotomise this finding as 'because it is paretic, it feels different'.

\section{CASE REPORT}

A 26 year old man presented with a 3 day history of facial asymmetry and right sided numbness of the face and tongue. On clinical examination we found a paralysis in the upper and lower quadrant of the right face and a diminished corneal reflex on the right. On sensory examination, he indicated a change of pinprick as well as temperature sensation in the right half of his face and mouth. No vesicular skin lesions could be seen and cerebrospinal fluid analysis was normal. There was no serological evidence for herpes simplex or herpes zoster (re)activation. A conduction block on the facial nerve in the petrous bone was documented by transcranial magnetic stimulation. He recovered completely within 2 weeks; no medication was prescribed.

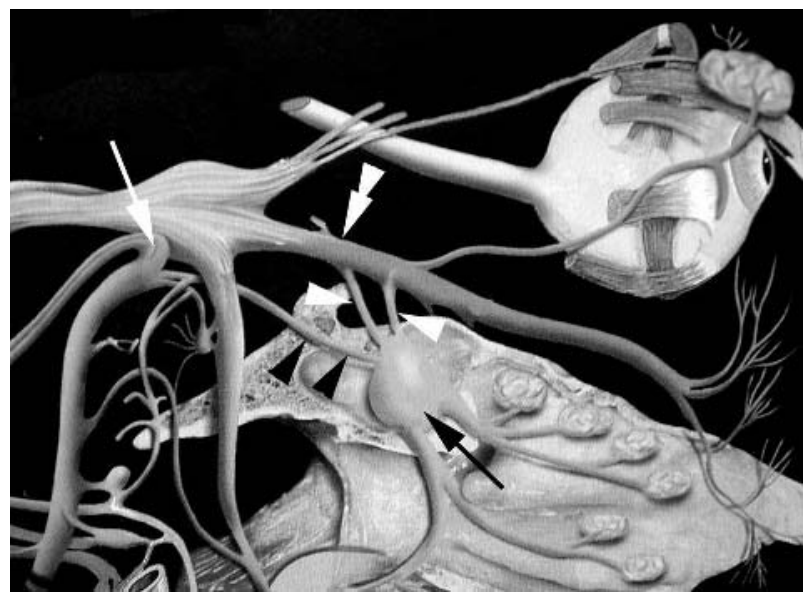

Figure 2 Anatomical illustration of the greater superficial petrosal nerve (GSPN) (black arrowheads). The GSPN can be followed from the geniculate ganglion of the facial nerve (white arrow) to the sphenopalatine ganglion (black arrow). Connecting branches (white arrowheads) between the maxillary nerve (double white arrowhead) and the sphenopalatine ganglion link the seventh and fifth cranial nerves at this site. Reproduced with permission: André Leblanc, Encephaloperipheral nervous system, Springer-Verlag, 2001. 


\section{DISCUSSION}

While ipsilateral numbness with a Bell's palsy is not rare in clinical practise, a good explanation has not yet been offered. The theory of involvement of the brainstem defies the electrophysiological findings with magnetic stimulation. ${ }^{5}$ Here we show contrast enhancement in the superficial greater petrosal nerve in a young man with typical Bell's palsy (figs la, b). This nerve is an anatomical connection between the facial nerve and the trigeminal and glossopharyngeal nerves. Herpetic viruses are known to spread along anatomical rather than functional connections. Of course, contrast enhancement demonstrates only local inflammation, not viral spread. This elegant mechanism was already suggested by Adour a quarter of a century ago. ${ }^{\circ}$

\section{Authors' affiliation}

L J Vanopdenbosch, K Verhoeven, Department of Neurology, AZ Sint Jan, Brugge, Belgium

JW Casselman, Department of Radiology, AZ Sint Jan, Brugge, Belgium

Competing interests: none declared
Correspondence to: Dr L J Vanopdenbosch, Department of Neurology, AZ Brugge, Ruddershove 10, 8000 Brugge, Belgium;

ludo.vanopdenbosch@azbrugge.be

Received 9 April 2004

In revised form 6 October 2004

Accepted 13 October 2004

\section{REFERENCES}

1 Murakami S, Mizobuchi M, Nakashiro Y, et al. Bell palsy and herpes simplex virus: identification of viral DNA in endoneurial fluid and muscle. Ann Intern Med 1996;124:27-30.

2 Russell JW. Bell palsy. In: Gilman S, ed. MedLink neurology. San Diego: MedLink Corporation. Available at: http://www.medlink.com. Accessed 16 October 2003

3 Adour KK, Byl FM, Hilsinger RL Jr, et al. The true nature of Bell's palsy: analysis of 1,000 consecutive patients. Laryngoscope 1978;88:787-801.

4 Hanner P, Badr G, Rosenhall U, et al. Trigeminal dysfunction in patients with Bell's palsy. Acta Otolaryngol 1986;101:224-30.

5 Glocker FX, Magistris MR, Rosler KM, et al. Magnetic transcranial and electrical stylomastoidal stimulation of the facial motor pathways in Bell's palsy: time course and relevance of electrophysiological parameters. Electroencephalogr Clin Neurophysiol 1994;93:113-20.

6 Adour KK. Cranial polyneuritis and Bell palsy. Arch Otolaryngol $1976 ; 102: 262-4$

\section{bmjupdates+}

bmjupdates+ is a unique and free alerting service, designed to keep you up to date with the medical literature that is truly important to your practice.

bmiupdates+ will alert you to important new research and will provide you with the best new evidence concerning important advances in health care, tailored to your medical interests and time demands.

Where does the information come from?

bmjupdates+ applies an expert critical appraisal filter to over 100 top medical journals A panel of over 2000 physicians find the few 'must read' studies for each area of clinical interest

Sign up to receive your tailored email alerts, searching access and more...

www.bmjupdates.com 